\title{
Analiza zjawiska przemocy wobec osób starszych mieszkających na terenie Gminy Miasto Szczecin*
}

\author{
Analysis of violence against elderly people residing in the City of Szczecin
}

\author{
Paulina Zabielska $\bowtie$ \\ Pomorski Uniwersytet Medyczny w Szczecinie, Katedra i Zakład Zdrowia Publicznego, ul. Żołnierska 48, 71-210 Szczecin \\ $\triangle$ paulina.zabielska@pum.edu.pl
}

\begin{abstract}
Introduction: Violence against elderly people is becoming pointed out more often in connection with the implementation of social policy. The incidence rate of violent events is expected to increase with the ageing of the population. Elderly people are both suffering from and using violent behaviour. It is crucial to investigate this problem thoroughly in order to introduce effective measures reducing violence.

The aim of this dissertation was to analyse the problem of violence among elderly people.

Materials and methods: A total number of 1299 cards created in the City of Szczecin from 2012 to 2013 was analysed. Documentation regarding elderly people ( 60 years old and more) was then selected. It resulted in 108 Blue Cards for 2012 and 157 Blue
\end{abstract}

Cards for 2013. The research method was a diagnostic survey based on the analysis of the documents.

Results: Descendants (children, grandchildren) were the group who most often used violence against elderly people. On the other hand, elderly people most often used violence against their spouses. There was a statistically significant correlation between physical violence and injury ( $\mathrm{p} \leq 0.05)$, as well as psychological violence and other types of behaviour ( $p \leq 0.05)$.

Conclusions: 1 . Socio-demographic factors are important elements determining the occurrence of violence in the family. 2. The degree of kinship has an impact on the character of family violence.

Keywords: violence; person using violence; person suffering from violence; elderly person; Blue Cards.

\begin{abstract}
ABSTRAKT
Wstęp: Coraz częściej w działaniach związanych z realizacją polityki społecznej zwraca się uwagę na przemoc w środowisku osób starszych, którego odsetek, ze względu na starzenie się społeczeństw, będzie wzrastać. Osoba starsza zarówno doznaje zachowań przemocowych, jak i je stosuje. Aby móc skutecznie realizować działania zmniejszające przemoc, kluczowe jest dokładne zbadanie zjawiska.

Celem pracy była analiza zjawiska przemocy w środowisku osób starszych.

Materiały i metody: Przeanalizowano 1299 formularzy Niebieskich Kart (NK) założonych w latach 2012-2013 na terenie Gminy Miasto Szczecin. W 2012 r. było to 577 kart, a w 2013 r. - 722 karty. Z zebranego materiału wyłoniono NK dotyczące osób starszych (60 lat i więcej). W 2012 r. było to 108 kart, a w 2013 r. - 157.
\end{abstract}

Metodą badawczą był sondaż diagnostyczny w oparciu o analizę dokumentów.

Wyniki: Osobami najczęściej stosującymi przemoc wobec osób starszych byli zstępni (dzieci, wnuki). Natomiast osoby starsze stosowały przemoc najliczniej wobec współmałżonka. Wykazano statystycznie istotny związek pomiędzy analizowanymi formami przemocy. Wystąpił on między przemocą fizyczną a uszkodzeniem ciała $(\mathrm{p} \leq 0,05)$, a także przemocą psychiczną i innymi rodzajami zachowań $(p \leq 0,05)$.

Wnioski: 1. Czynniki socjodemograficzne to ważne elementy warunkujące występowanie przemocy w rodzinie. 2. Stosunek pokrewieństwa ma wpływ na charakter występowania przemocy w rodzinie.

Słowa kluczowe: przemoc; osoba stosująca przemoc; osoba doznająca przemocy; osoba starsza; Niebieskie Karty.

\section{WSTĘP}

Przemoc w rodzinie stanowi jeden $\mathrm{z}$ istotniejszych problemów polityki społecznej państw na całym świecie. Zjawisko to towarzyszy ludzkości od zawsze, przyjmuje różne formy i jest określane jako demokratyczne - dotyczy wszystkich grup społecznych. Niestety, ciągle istnieje przekonanie o występowaniu przemocy tylko w środowisku tzw. marginesu społecznego, a przecież każdy może znaleźć się w roli świadka przemocy, osoby doznającej przemocy (ODP) bądź osoby stosującej przemoc (OSP) $[1,2,3]$. Corocznie bardzo dużo ludzi doświadcza tego problemu. Przemoc wywołuje osamotnienie, strach oraz brak poczucia bezpieczeństwa, niezależnie od tego, kogo dotyczy, kto ją stosuje i w jakiej formie występuje [4].

W Ustawie o przeciwdziałaniu przemocy w rodzinie z dnia 29 lipca 2005 r. zdefiniowano pojęcie przemocy w rodzinie,

* Zwięzła wersja rozprawy doktorskiej przyjętej przez Radę Wydziału Nauk o Zdrowiu Pomorskiego Uniwersytetu Medycznego w Szczecinie. Promotor: prof. dr hab. n. zdr. Beata Karakiewicz. Oryginał obejmuje: 191 stron, 76 rycin, 53 tabele, 168 pozycji piśmiennictwa. Pracę wykonano w ramach projektu młodego naukowca realizowanego w okresie od 2014 do 2016 roku, finansowanego ze środków dotacji Ministerstwa Nauki i Szkolnictwa Wyższego (nr MB-303-131/14). 
uznając ją za ,jednorazowe albo powtarzające się umyślne działanie lub zaniechanie naruszające prawa lub dobra osobiste członków rodziny, w szczególności narażające te osoby na niebezpieczeństwo utraty życia, zdrowia, naruszające ich godność, nietykalność cielesną, wolność, w tym seksualną, powodujące szkody na ich zdrowiu fizycznym lub psychicznym, a także wywołujące cierpienia i krzywdy moralne u osób dotkniętych przemocą" [5].

Od wielu lat zauważalne jest zjawisko starzejących się społeczeństw, którego przyczyna to spadek liczby urodzeń i jednoczesny wzrost długości życia. Światowa Organizacja Zdrowia (WHO) przewiduje, że do 2025 r. liczba osób 60+ wzrośnie ponad 2-krotnie. Zjawisko to może mieć wpływ na zwiększanie się problemu przemocy wobec osób starszych $[6,7,8,9]$. Niestety, jest to kwestia nadal mało zbadana. Bardzo trudno o profilaktykę zjawiska przemocy, ponieważ najczęściej dokonuje się ono bez świadków [10]. Należy wspomnieć, iż przemoc związana z seniorami jest istotnym problemem zdrowia publicznego, a uwikłanie w zachowania przemocowe może powodować negatywne skutki zdrowotne [11].

Z raportu WHO wynika, że w Europie aż 8500 osób w wieku $60+$ co roku umiera w wyniku zabójstwa; w ok. 2500 przypadków dokonują go członkowie rodziny, natomiast 1\% zgonów jest wynikiem zaniedbania [12].

Na podstawie badań ogólnopolskich PolSenior wykazano, że osoby starsze czują się zaniedbywane. Najwyższy odsetek poczucia zaniedbania był w województwie podlaskim - 20,8\%, natomiast najniższy w województwie lubuskim i lubelskim $7,3 \%$ [13].

Organizacja charytatywna zajmująca się problematyką przemocy wobec seniorów - Action on Elder Abuse przedstawiła portret psychologiczny osoby starszej doznającej przemocy. Wyróżniono w nim cechy takie jak duma i bezsilność, które są hamującymi czynnikami zgłaszania przemocy [14, 15]. Uwzględniając różne kryteria, scharakteryzowano ODP:

- kryterium płci - osobami doznającymi przemocy częściej są kobiety,

- kryterium wieku - dzieci oraz osoby starsze,

- kryterium stanu zdrowia - osoby niepełnosprawne intelektualnie i/lub fizycznie [16].

Bardzo trudno skonstruować jednoznaczny opis osoby stosującej przemoc [17]. Przyczynami przemocy stosowanej przez osoby starsze są: zaburzenia zachowania, problemy psychologiczne, uzależnienia, zły stan zdrowia fizycznego, trudna lub bardzo dobra sytuacja finansowa, urazy, wydarzenia z przeszłości [18]. Bardzo często są to również zespoły otępienne [19, 20].

Osobami stosującymi przemoc najczęściej są mężczyźni charakteryzujący się brakiem umiejętności kontroli nad własnym gniewem, niskim poziomem samooceny, brakiem asertywności, kłótliwością oraz uzależnieniem od alkoholu. Agresja może wynikać z powodu ograniczenia spożywania alkoholu lub jego nadmiernego spożycia. Głównym celem OSP jest uzyskanie kontroli nad członkami rodziny i podporządkowanie ich swojej osobie [21, 22].

Celem pracy była analiza zjawiska przemocy w środowisku osób starszych.

\section{MATERIAtY I METODY}

Przeanalizowano 1299 Niebieskich Kart (NK) założonych w latach 2012-2013 na terenie Gminy Miasto Szczecin. W 2012 r. było to 577 kart, a w 2013 r. - 722 karty. Z zebranego materiału wyłoniono NK dotyczące osób starszych (60 lat i więcej). W 2012 r. było to 108 kart, a w 2013 r. - 157. Metodą badawczą był sondaż diagnostyczny w oparciu o analizę dokumentów.

W celu uzyskania zgody na realizację badania jego projekt został przedłożony Komisji Bioetycznej Pomorskiego Uniwersytetu Medycznego w Szczecinie (PUM). W dniu 18 czerwca 2014 r. uzyskano informację - KB 0012/47/06/2014, iż zaprojektowany proces badawczy nie wymaga opinii Komisji Bioetycznej PUM.

Rozmiar przemocy na badanym obszarze opracowano na podstawie pozyskanych danych z Biura Informacji Publicznej Urzędu Miasta Szczecin, które dotyczyły osób 60+ mieszkających na terenie Gminy Miasto Szczecin w latach 2012-2013, z podziałem na rejony (tab. 1).

TABELA 1. Odsetek osób starszych uwikłanych w zachowania przemocowe na tle ogólnej liczby ludności 60+ w latach 2012-2013 i łączna liczba Niebieskich Kart (NK) założonych w latach 2012 i 2013

\begin{tabular}{|c|c|c|c|c|c|}
\hline \multirow{2}{*}{\multicolumn{2}{|c|}{$\begin{array}{c}\text { Osoby } 60 \text { + zamieszkujące } \\
\text { poszczególne rejony } \\
\text { w latach 2012-2013 } \\
\text { Ogółem (n) }\end{array}$}} & \multicolumn{4}{|c|}{$\begin{array}{l}\text { Osoby starsze doznające i stosujące } \\
\text { przemoc w poszczególnych rejonach } \\
\text { w latach 2012-2013 }\end{array}$} \\
\hline & & częstość & ODP & OSP & ogółem \\
\hline \multirow{2}{*}{ Północ } & \multirow{2}{*}{15065} & $n$ & 69 & 38 & 107 \\
\hline & & $\%$ & 0,46 & 0,25 & 0,71 \\
\hline \multirow{2}{*}{ Prawobrzeże } & \multirow{2}{*}{20702} & $\mathrm{n}$ & 39 & 27 & 66 \\
\hline & & $\%$ & 0,19 & 0,13 & 0,32 \\
\hline \multirow{2}{*}{ Zachód } & \multirow{2}{*}{45149} & $\mathrm{n}$ & 40 & 33 & 73 \\
\hline & & $\%$ & 0,09 & 0,07 & 0,16 \\
\hline \multirow{2}{*}{ Śródmieście } & \multirow{2}{*}{49432} & $\mathrm{n}$ & 47 & 27 & 74 \\
\hline & & $\%$ & 0,10 & 0,05 & 0,15 \\
\hline \multirow{3}{*}{\multicolumn{2}{|c|}{ Liczba założonych NK }} & 2012 r. & 577 & $44,4 \%$ & \\
\hline & & 2013 r. & 722 & $55,6 \%$ & \\
\hline & & ogółem & 1299 & $100,0 \%$ & \\
\hline
\end{tabular}

ODP - osoby doznające przemocy; OSP - osoby stosujące przemoc

\section{WYNIKI}

\section{Osoby starsze doznające przemocy}

Spośród osób starszych doznających przemocy dominowały kobiety, stanowiąc 77,44\% ODP (151 osób). Mężczyźni stanowili grupę, która rzadziej doznawała przemocy (44 osoby; 22,56\%). Kobiety - ofiary przemocy miały przeciętnie niespełna 69 lat $(\overline{\mathrm{x}} \pm \mathrm{SD}=68,45 \pm 7,67)$, natomiast mężczyźni 66,98 $\pm 6,89$. Wartości mediany wieku kobiet i mężczyzn wyniosły odpowiednio: 66 i 65 lat (tab. 2).

Sprawdzono także stopień pokrewieństwa osób stosujących przemoc wobec osób starszych. W 105 (53,8\%) przypadkach byli to zstępni (dzieci, wnuki). Następną grupę stanowili współmałżonkowie - 53 osoby (27,2\%). Trzecią co do częstości była grupa osób niespokrewnionych z ODP (np. konkubent/ konkubina) - 23 (11,8\%). Najrzadziej przemoc stosowana była 
TABELA 2. Opis statystyczny płci i wieku osób doznających przemocy

\begin{tabular}{lccccccc}
\multicolumn{1}{c}{ Pteć } & $\mathbf{n}$ & $\mathbf{\%}$ & $\overline{\mathbf{x}}$ & $\mathrm{SD}$ & $\mathbf{D}$ & $\mathbf{M i n}_{\mathbf{-}}-\mathbf{m a x}$. & $\mathbf{Q}_{\mathbf{1}}-\mathbf{Q}_{\mathbf{3}}$ \\
\hline Kobiety & 151 & 77,44 & 68,87 & 7,81 & 61 & $60-89$ \\
\hline Mężczyźni & 44 & 22,56 & 66,98 & 6,89 & 66 & $60-88$ & 65 \\
\hline
\end{tabular}

TABELA 3. Stopień pokrewieństwa osoby doznającej przemocy (ODP) z osobą stosującą przemoc

\begin{tabular}{|c|c|c|c|c|c|c|c|c|c|c|}
\hline Płeć OD & & Wstępny & Zstępny & $\begin{array}{l}\text { Pokrewieństwo } \\
\text { w linii bocznej }\end{array}$ & Małżonek & $\begin{array}{l}\text { Osoba } \\
\text { obca }\end{array}$ & $\begin{array}{c}\text { Brak } \\
\text { pokrewieństwa }\end{array}$ & $\begin{array}{c}\text { Brak } \\
\text { danych }\end{array}$ & Ogółem & Statystyka \\
\hline \multirow{2}{*}{ Kobiety } & $\mathrm{n}$ & 1 & 79 & 2 & 47 & 2 & 16 & 4 & 151 & \multirow{4}{*}{$\begin{array}{l}H=7,743 \\
p=0,258\end{array}$} \\
\hline & $\%$ & 0,5 & 40,5 & 1,0 & 24,1 & 1,0 & 8,2 & 2,1 & 77,4 & \\
\hline \multirow{2}{*}{ Mężczyźni } & $\mathrm{n}$ & 1 & 26 & 2 & 6 & 1 & 7 & 1 & 44 & \\
\hline & $\%$ & 0,5 & 13,3 & 1,0 & 3,1 & 0,5 & 3,6 & 0,5 & 22,6 & \\
\hline \multirow{2}{*}{ Ogółem } & $\mathrm{n}$ & 2 & 105 & 4 & 53 & 3 & 23 & 5 & 195 & \\
\hline & $\%$ & 1,0 & 53,8 & 2,1 & 27,2 & 1,5 & 11,8 & 2,6 & 100,0 & \\
\hline
\end{tabular}

przez wstępnych (np. rodzice) - 2 osoby; 1,0\%. Uwzględniając podział na płeć, nie wykazano istotnych różnic od ogółu. Również różnice między płciami nie były statystycznie istotne ( $p>0,05)$. Uwagę można zwrócić na częstość stosowania przemocy przez osoby niespokrewnione (tab. 3).

Badano także formy przemocy stosowane w stosunku do osób starszych. Próbowano odpowiedzieć na pytanie: Czy istnieje związek pomiędzy stosowanymi zachowaniami? Zaprezentowane w tabeli 4 wyniki wskazują, iż statystycznie istotny związek wystąpił między przemocą fizyczną i uszkodzeniem ciała ( $\mathrm{p} \leq 0,05)$, a także przemocą psychiczną i innymi rodzajami zachowań $(\mathrm{p} \leq 0,05)$.

TABELA 4. Poszukiwanie związku pomiędzy formami przemocy występującej u osoby doznającej przemocy

\begin{tabular}{|c|c|c|c|c|c|}
\hline \multicolumn{2}{|c|}{$\begin{array}{c}\text { Forma } \\
\text { przemocy }\end{array}$} & \multirow{2}{*}{$\begin{array}{c}\text { Uszkodze- } \\
\text { nie ciała }\end{array}$} & \multirow{2}{*}{$\begin{array}{c}\text { Psychiczna } \\
0,244^{*}\end{array}$} & \multirow{2}{*}{$\begin{array}{c}\text { Seksualna } \\
0,619^{*}\end{array}$} & \multirow{2}{*}{$\begin{array}{c}\begin{array}{c}\text { Inne } \\
\text { rodzaje } \\
\text { zachowań }\end{array} \\
0,560^{*}\end{array}$} \\
\hline $\mathrm{Fi}$ & $\mathrm{X}^{2} / \mathrm{H}^{*}$ & & & & \\
\hline$r 12 y(2 \pi 1 d$ & $p$ & 0,000 & 0,621 & 0,431 & 0,454 \\
\hline \multirow{2}{*}{$\begin{array}{l}\text { Uszkodze- } \\
\text { nie ciała }\end{array}$} & $\mathrm{X}^{2} / \mathrm{H}^{*}$ & & $0,003^{*}$ & $2,078^{*}$ & 0,065 \\
\hline & $\mathrm{p}$ & & 0,959 & 0,149 & 0,799 \\
\hline \multirow{2}{*}{ Psychiczna } & $\mathrm{X}^{2} / \mathrm{H}^{*}$ & & & $0,053^{*}$ & $7,830^{*}$ \\
\hline & $p$ & & & 0,949 & 0,005 \\
\hline \multirow{2}{*}{ Seksualna } & $\mathrm{X}^{2} / \mathrm{H}^{*}$ & & & & $1,324^{*}$ \\
\hline & $\mathrm{p}$ & & & & 0,250 \\
\hline
\end{tabular}

Ważnym elementem w ocenie okoliczności stosowania przemocy jest sprawdzenie miejsca zdarzenia. Do dokumentacji Niebieskiej Karty (NK) wprowadza się informację o tym, czy w miejscu zamieszkania były widoczne ślady awantury. Na rycinie 1 przedstawiono rozkład odsetkowy dotyczący opisu miejsca zdarzenia. W przypadku 78 (40,0\%) osób starszych doznających przemocy informacje te nie były wprowadzone

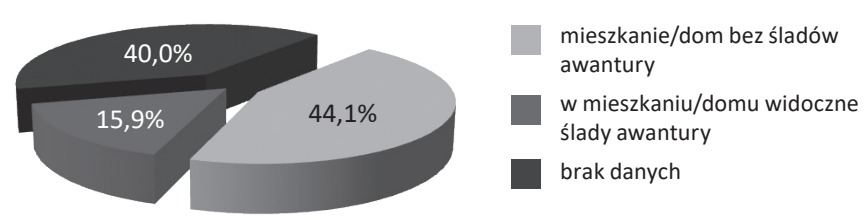

RYCINA 1. Rozkład odsetkowy występowania śladów awantury w miejscu zamieszkania osoby doznającej przemocy

do formularza A. Widoczne ślady awantury zaobserwowano u 31 (15,9\%) osób, natomiast u 86 (44,1\%) miejsce zamieszkania było wolne od tego rodzaju śladów.

\section{Osoby starsze stosujące przemoc}

W grupie osób starszych stosujących przemoc dominowali mężczyźni. Stanowili oni 88,8\% (111 osób) grupy OSP. Stosowanie przemocy przez kobiety dotyczyło tylko nieco ponad 10\% przypadków (11,2\%; 14 osób). Obserwacji poddano także wiek sprawców, różnicując jego wartości względem kobiet i mężczyzn. Pomimo że uzyskanych wartości nie charakteryzowała istotność statystyczna, to przeciętnie kobiety stosujące przemoc miały 68 lat $(\overline{\mathrm{x}} \pm \mathrm{SD}=68,21 \pm 8,94)$, natomiast mężczyźni byli młodsi; średnio w wieku 66 lat $(\overline{\mathrm{x}} \pm \mathrm{SD}=66,57 \pm 5,95)$. Miary średnie nie znajdywały potwierdzenia w zastosowanych miarach pozycyjnych. Modalny wiek kobiet wynosił 60 lat, a mężczyzn 62 lata. Odmienne wartości zaobserwowano także dla median: 63 lata w grupie kobiet i 65 lat - mężczyzn (tab. 5).

Również stopień pokrewieństwa osób starszych stosujących przemoc został poddany weryfikacji. W 77 (61,6\%) przypadkach byli nimi małżonkowie ofiar. Kolejną, mniej liczną grupę stanowili wstępni (18 osób; 14,4\%) oraz osoby, u których pokrewieństwo z ODP nie występowało, m.in. konkubent (20 osób; 16,0\%). Zstępni i pokrewieństwo w linii bocznej wystąpiło tylko odpowiednio 4 i 2 razy w badanej grupie. Jedna osoba była obca dla OSP, a w 3 przypadkach danych nie

TABELA 5. Opis statystyczny płci i wieku osób doznających przemocy

\begin{tabular}{|c|c|c|c|c|c|c|c|c|}
\hline Płeć & $\mathrm{n}$ & $\%$ & $\overline{\mathrm{x}}$ & SD & D & Min.-max. & Me & $Q_{1}-Q_{3}$ \\
\hline Kobiety & 14 & 11,2 & 68,21 & 8,94 & 60 & $60-86$ & 63 & $60-86$ \\
\hline Mężczyźni & 111 & 88,8 & 66,57 & 5,95 & 62 & $60-88$ & 65 & $60-88$ \\
\hline
\end{tabular}


TABELA 6. Stopień pokrewieństwa osoby stosującej przemoc (OSP) z osobą dotkniętą przemocą

\begin{tabular}{|c|c|c|c|c|c|c|c|c|c|c|}
\hline Płeć OS & & Wstępny & Zstępny & $\begin{array}{l}\text { Pokrewieństwo } \\
\text { w linii bocznej }\end{array}$ & Małżonek & $\begin{array}{l}\text { Osoba } \\
\text { obca }\end{array}$ & $\begin{array}{c}\text { Brak } \\
\text { pokrewieństwa }\end{array}$ & $\begin{array}{c}\text { Brak } \\
\text { danych }\end{array}$ & Ogółem & Statystyka \\
\hline \multirow{2}{*}{ Kobiety } & $\mathrm{n}$ & 2 & 2 & 1 & 7 & 0 & 2 & 0 & 14 & \multirow{6}{*}{$\begin{array}{l}H=9,960 \\
p=0,126\end{array}$} \\
\hline & $\%$ & 1,6 & 1,6 & 0,8 & 5,6 & 0,0 & 1,6 & 0,0 & 11,2 & \\
\hline \multirow{2}{*}{ Mężczyźni } & $n$ & 16 & 2 & 1 & 70 & 1 & 18 & 3 & 111 & \\
\hline & $\%$ & 12,8 & 1,6 & 0,8 & 56,0 & 0,8 & 14,4 & 2,4 & 88,8 & \\
\hline \multirow{2}{*}{ Ogółem } & $\mathrm{n}$ & 18 & 4 & 2 & 77 & 1 & 20 & 3 & 125 & \\
\hline & $\%$ & 14,4 & 3,2 & 1,6 & 61,6 & 0,8 & 16,0 & 2,4 & 100,0 & \\
\hline
\end{tabular}

podano. Uwzględniając podział na płeć, nie wykazano istotnych różnic do ogółu (tab. 6). Również różnice między płciami nie były istotne statystycznie ( $p>0,05)$.

Poszukiwano również związku pomiędzy analizowanymi formami zachowań przemocowych stosowanych przez seniorów. Statystycznie istotny związek wystąpił między przemocą fizyczną a uszkodzeniem ciała $(\mathrm{p} \leq 0,05)$ oraz przemocą psychiczną i innymi rodzajami zachowań $(\mathrm{p} \leq 0,05)$ - tabela 7 .

TABELA 7. Poszukiwanie związku pomiędzy formami przemocy stosowanymi przez osoby stosujące przemoc

\begin{tabular}{|c|c|c|c|c|c|}
\hline \multicolumn{2}{|c|}{ Forma przemocy } & \multirow{2}{*}{$\begin{array}{c}\begin{array}{c}\text { Uszkodze- } \\
\text { nie ciata }\end{array} \\
12,708\end{array}$} & \multirow{2}{*}{$\begin{array}{c}\text { Psychiczna } \\
0,107^{\star}\end{array}$} & \multirow{2}{*}{$\begin{array}{c}\text { Seksualna } \\
1,165^{\star}\end{array}$} & \multirow{2}{*}{$\begin{array}{c}\begin{array}{c}\text { Inne } \\
\text { rodzaje } \\
\text { zachowań }\end{array} \\
2,266^{*}\end{array}$} \\
\hline \multirow{2}{*}{ Fizyczna } & $\mathrm{X}^{2} / \mathrm{H}^{*}$ & & & & \\
\hline & $p$ & 0,000 & 0,744 & 0,280 & 0,132 \\
\hline \multirow{2}{*}{$\begin{array}{l}\text { Uszkodze- } \\
\text { nie ciała }\end{array}$} & $\mathrm{X}^{2} / \mathrm{H}^{*}$ & & $1,325^{*}$ & $0,812^{*}$ & 0,055 \\
\hline & $\mathrm{p}$ & & 0,250 & 0,367 & 0,814 \\
\hline \multirow{2}{*}{ Psychiczna } & $\mathrm{X}^{2} / \mathrm{H}^{*}$ & & & $0,088^{*}$ & 4,720 * \\
\hline & $p$ & & & 0,766 & 0,030 \\
\hline \multirow{2}{*}{ Seksualna } & $\mathrm{X}^{2} / \mathrm{H}^{*}$ & & & & $2,346^{*}$ \\
\hline & $p$ & & & & 0,126 \\
\hline
\end{tabular}



RYCINA 2. Rozkład odsetkowy występowania śladów awantury w miejscu zamieszkania osoby stosującej przemoc

Podobnie jak w przypadku osób starszych doznających przemocy, także względem stosujących przemoc przeprowadzono analizę miejsca zdarzenia. Na rycinie 2 przedstawiono rozkład procentowy wyglądu miejsca podejmowanej procedury NK. W 54 (43,20\%) przypadkach w miejscu zamieszkania OSP nie zaobserwowano śladów stosowania przemocy. Niestety, aż u 48 (38,40\%) sprawców nie podano informacji o wyglądzie mieszkania/domu. Podczas 23 (18,40\%) interwencji w miejscu zamieszkania były obecne ślady awantury.

\section{DYSKUSJA}

Zmienne socjodemograficzne, które przeanalizowano w pracy względem badanej grupy, to płeć, wiek oraz pokrewieństwo z osobą stosującą przemoc. Charakteryzując objętą badaniem grupę 195 osób starszych doznających przemocy, wykazano, iż kobiety częściej niż mężczyźni były ofiarami tego zjawiska. Wyniki badań własnych znalazły potwierdzenie w literaturze $[23,24]$.

Z badań przeprowadzonych przez Towarzystwo Pielęgniarek Środowiskowych w Wielkiej Brytanii wynika, że liczniejszą grupą osób doznających nadużyć są właśnie kobiety - 67\% w stosunku do 33\% mężczyzn [23]. Proporcje te potwierdzają również pomiary amerykańskie przeprowadzone przez National Center on Elder Abuse, w których kobiety stanowiły ponad $68 \%$ ofiar przemocy wśród osób starszych [24]. Wnioski te są tożsame z badaniami własnymi, gdzie kobiety tworzyły grupę prawie 78\% osób doznających przemocy, a mężczyźni $22,56 \%$. Może to wynikać z uwarunkowań społeczno-kulturowych i niechęci mężczyzn przed przyznaniem się do bycia ofiarą. Takie ujawnienie często wiąże się ze stygmatyzacją ze strony środowiska [25]. Jednak istnieją doniesienia, w których płeć męska przeważa w kwestii doznawania przemocy. Jednym z nich jest badanie miejskiej populacji chińskiej (Nanjing, Chiny), gdzie 145 osób doznawało zachowań przemocowych, a ponad połowa z nich to byli właśnie mężczyźni (59\%) [26].

Według WHO osobami starszymi są ludzie od 60. r.ż. [27], dlatego w badaniach własnych analizowano przypadki osób mających 60 i więcej lat. Na podstawie wyników wykazano, że kobiety doznające przemocy miały przeciętnie 69 lat, a mężczyźni prawie 67. Mediana wieku dla obydwu grup wynosiła 65 lat. Podobne wnioski uzyskali badacze z Quebecu w Kanadzie oraz Chin [26, 28]. Kanadyjczycy w latach 2011-2012 przeprowadzili 1765 wywiadów z osobami starszymi. Na ich podstawie można było stwierdzić, że wiek ofiary był związany z przemocą w rodzinie; częściej doznawały jej osoby w przedziale wiekowym 65-74 lat, natomiast osoby w wieku 75 lat i więcej były ofiarami rzadziej [28]. W badaniach Dong i wsp. wykazali, że średni wiek 145 osób, które doznawały przemocy, wynosił 69 lat [26].

W badaniach własnych dowiedziono, iż osobami najczęściej stosującymi przemoc w badanej grupie wiekowej byli zstępni, czyli dzieci bądź wnuki oraz małżonkowie. Te wyniki potwierdzają badania ankietowe przeprowadzone w $2010 \mathrm{r}$. wśród dyrektorów i kierowników ośrodków pomocy społecznej województwa opolskiego. Ankiety rozpowszechniał zespół pracowników Obserwatorium Integracji Społecznej Regionalnego Ośrodka Pomocy Społecznej w Opolu. Według nich osoby, które stosują przemoc wobec seniorów, 
to najczęściej syn lub zięć (takiej odpowiedzi udzieliło 79,5\% respondentów) oraz współmałżonek bądź konkubent $(47,7 \%$ wskazań) [29]. Tożsame odpowiedzi dotyczące pokrewieństwa zaprezentowano w badaniach prowadzonych w rejonowym ośrodku zdrowia w Barcelonie, gdzie przypuszczalnie najczęstszymi sprawcami wśród badanych przypadków byli syn lub córka (57\%), małżonek (8\%) bądź pasierbowie (23\%) [30].

Badania nad osobami starszymi stosującymi przemoc nie są prowadzone w szerokim zakresie, stąd olbrzymia trudność dotarcia do jakichkolwiek danych na ten temat. W analizowanej literaturze autorzy skupiają się nad osobą starszą jako ofiarą przemocy. Zarówno polskie, jak i międzynarodowe doniesienia przynoszą informacje, że osobami zdecydowanie częściej stosującymi przemoc byli mężczyźni [21, 31]. Taki sam stan rzeczy wykazano w badaniach własnych, gdzie prawie 90\% osób starszych stosujących przemoc to przedstawiciele płci męskiej, natomiast kobiety stanowiły 10,4\%.

Na podstawie badań własnych oraz innych autorów można stwierdzić, że przemoc to niezwykle ważny problem, a jej skutki pozostają na całe życie. Dlatego zasługuje ona na zwiększenie uwagi ze strony naukowców, pracowników ochrony zdrowia, przedstawicieli pomocy społecznej oraz innych profesjonalistów [32,33].

\section{WNIOSKI}

1. Czynniki socjodemograficzne to ważne elementy warunkujące występowanie przemocy w rodzinie. Nasilenie negatywnych oddziaływań nie zmienia się wraz z wiekiem. Kobiety częściej są osobami doznającymi przemocy, a mężczyźni stosującymi przemoc.

2. Stosunek pokrewieństwa ma wpływ na charakter występowania przemocy w rodzinie. Osoby starsze najczęściej doznają przemocy ze strony zstępnych (dzieci, wnuków), natomiast stosują ją w stosunku do małżonka.

\section{PIŚMIENNICTWO}

1. Kowalczyk M, Łącka T. Przemoc i jej mechanizmy w związkach partnerskich. Paedagogia Christiana 2011;27:1.

2. Spurek S. Przeciwdziałanie przemocy w rodzinie. Warszawa: Wydaw. Wolters Kluwer Business; 2012.

3. Clancy M, McDaid B, O'Neill D, O'Brien JG. National profiling of elder abuse referrals. Age Ageing 2011;40:346-52.

4. Pruszyński J. Rozpoznawanie objawów przemocy u pacjentów zgłaszających się do przychodni i oddziałów neurologicznych. Post Nauk Med 2009;11:894-8.

5. Ustawa z dnia 29 lipca 2005 r. o przeciwdziałaniu przemocy w rodzinie (Dz.U. z 2005 r., nr 180, poz. 1493).

6. Zaidi A. Features and challenges of population ageing: the European perspective. Vienna: European Centre for Social Welfare Policy and Research; 2008. p. 49. http://www.euro.centre.org/data/1204800003_27721.pdf (25.09.2015).

7. Strategie działania w starzejącym się społeczeństwie. Tezy i rekomendacje. Warszawa: Biuro Rzecznika Praw Obywatelskich. 2012. https:// www.rpo.gov.pl/pliki/13541772380.pdf (25.09.2015).
8. Portret generacji 50+ w Polsce i w Europie. Wyniki badania zdrowia, starzenia się i przechodzenia na emeryturę w Europie (SHARE). Warszawa: Instytut Badań Edukacyjnych; 2014.

9. Brownell P. Neglect, abuse and violence against older women: Definitions and research frameworks (Review article). SEEJPH 2014. doi 10.12908/ SEEJPH-2014-03.

10. Czabański A, Lewicka-Pańczak K. Przemoc wobec osób starszych w świetle danych Miejskiego Ośrodka Pomocy Rodzinie w Poznaniu. Now Lek 2012;81(1):55-9.

11. Dong X. Medical implications of elder abuse and neglect. Clin Geriatr Med 2005;21:293-313.

12. European report on preventing elder maltreatment. Copenhagen: World Health Organization. Regional Office for Europe; 2011. http://www.euro. who.int/__data/assets/pdf_file/0010/144676/e95110.pdf (25.09.2015).

13. Mossakowska M, Więcek A, Błędowski P, editors. Aspekty medyczne, psychologiczne, socjologiczne i ekonomiczne starzenia się ludzi w Polsce. Poznań: Termedia Wydawnictwa Medyczne; 2012.

14. Skwarzyńska E. Przemoc wobec osób starszych w Wielkiej Brytanii. Niebieska Linia 2005;4. http://www.niebieskalinia.pl/pismo/wydania/ dostepne-artykuly/4608-przemoc-wobec-osob-starszych-w-wielkiejbrytanii (7.01.2016).

15. What is elder abuse? Action on elder abuse. http://elderabuse.org.uk/ what-is-elder-abuse/ (7.01.2016).

16. Sygit E, Ossowski R. Przemoc wobec osób starszych ze względu na ich wiek, płeć i wykształcenie. Gerontol Pol 2008;16(3):163-8.

17. Chmurska E. Sprawcy przemocy wobec bliskich. Niebieska Linia 2009;2. http://www.niebieskalinia.pl/pismo/wydania/dostepne-artykuly/4995sprawcy-przemocy-wobec-bliskich (7.01.2016).

18. Johannesen M, Logiudice D. Elder abuse: a systematic review of risk factors in community-dwelling elders. Age Ageing 2013;42:292-8.

19. Jackson JL, Mallory R. Aggression and violence among elderly patients, a growing health problem. J Gen Intern Med 2009;24(10):1167-8.

20. Braun M, Scholz U, Bailey B, Perren S, Hornung R, Martin M. Dementia caregiving in spousal relationships: a dyadic perspective. Aging Ment Health 2009;13(3):426-36.

21. Roberto KA, McCann BR, Brossoie N. Intimate partner violence in late life: An analysis of National News Reports. J Elder Abuse Negl 2013;25(3): 230-41.

22. Ogólnopolskie badanie profesjonalistów realizujących programy oddziaływań korekcyjno-edukacyjnych dla osób stosujących przemoc w rodzinie. Instytut Millward Brown SMG/KRC. Raport z badania zrealizowanego dla MPiPS; 2011. https://www.mpips.gov.pl/gfx/mpips/userfiles/_ public/1_NOWA\%20STRONA/Przemoc\%20w\%20rodzinie/dane\%20 statystyczne/4\%20RAPORT_PRZEMOC_W_RODZINIE_PROFESJONALISCI_FIN.pdf (7.01.2016).

23. Baumann K. Osoby w okresie późnej dorosłości jako ofiary nadużyć. Gerontol Pol 2006;14(3):119-24.

24. Staręga A. Przemoc wobec osób starszych. Niebieska Linia 2003;5. http:// www.niebieskalinia.pl/pismo/wydania/dostepne-artykuly/4339-przemoc-wobec-osob-starszych (7.01.2016).

25. Mielnik S. Mężczyzna jako ofiara przemocy domowej. Biuletyn RPO „Przeciw przemocy domowej. Ręce są do przytulania”. Warszawa: 2010. https:// www.rpo.gov.pl/sites/default/files/Biuletyn_RPO_Konferencja_Rzecznika_Praw_Obywatelskich_Przeciw_przemocy_domowej_Rece_sa_do_ przytulania_-_22_lutego_2010_r..pdf (26.09.2015).

26. Dong X, Simon MA, Gorbien M. Elder abuse and neglect in an urban chinese population. J Elder Abuse Negl 2007;19(3-4):79-96

27. Prosped working definitione of an older person in Afrika for the MDS Project. World Health Organization. http://www.who.int/healthinfo/ survey/ageingdefnolder/en/ (12.01.2016).

28. Préville M, Mechakra-Tahiri SD, Vasiliadis HM, Mathieu V, Quesnel L, Gontijo-Guerra S, et al. Family violence among older adult patients consulting in primary care clinics: results from the ESA (Enquête sur la santé des aînés) Services Study on Mental Health and Aging. Can J Psychiatry 2014;59(8):426-33.

29. Przemoc wobec osób starszych w województwie opolskim na podstawie informacji uzyskanych z ośrodków pomocy społecznej. Opole: Obserwatorium Integracji Społecznej Regionalnego Ośrodka Polityki Społecznej w Opolu; 2010. http://ois.rops-opole.pl/download/Przemoc\%20-\%20 Osoby\%20starsze\%20-\%20badanie.pdf (12.01.2016). 
30. Ruiz Sanmartín A, Altet Torner J, Porta Martí N, Duaso Izquierdo P, Coma Solé M, Requesens Torrellas N. Violencia doméstica: prevalencia de sospecha de maltrato a ancianos. Aten Primaria 2001;27(5):331-4.

31. Rudnicka-Drożak E, Latalski M. Zjawisko przemocy wobec osób starszych po 65. r.ż., mieszkańców rejonów wiejskich województwa lubelskiego w porównaniu do rejonów miejskich. Probl Hig Epidemiol 2006;Suppl:84.
32. Beach SR, Schulz R, Castle NG, Rosen J. Financial exploitation and psychological mistreatment among older adults: differences between African Americans and Non-African Americans in a population-based survey. Gerontologist 2010;50(6):744-57.

33. Romańska A, Mroczek B, Karakiewicz B. Przemoc w rodzinie jako istotny problem medycyny rodzinnej. Fam Med Prim Care Rev 2008;10(3):641-7. 